\title{
(2) OPEN ACCESS \\ What benefits do healthcare organisations receive from leadership and management development programmes? A systematic review of the evidence
}

\author{
Gabriel Seidman $\odot,{ }^{1}$ Laurie Pascal, ${ }^{2}$ John McDonough ${ }^{2}$
}

${ }^{1}$ Global Health and Population, Harvard T H Chan School of Public Health, Boston, Massachusetts, USA ${ }^{2}$ Health Policy and Management, Harvard T H Chan School of Public Health, Boston, Massachusetts, USA

\section{Correspondence to}

Dr Gabriel Seidman, Global Health and Population, Harvard T H Chan School of Public Health, Boston, MA 02115 , USA;

gabriel.seidman@gmail.com

Received 14 February 2019 Revised 13 August 2019 Accepted 12 October 2019 Published Online First 4 February 2020
ABSTRACT

Introduction Leadership and management training/ development programmes have gained increasing institutional attention in healthcare organisations, and they have a wide variety of formats and approaches. However, limited evidence exists about effects of these programmes for the organisations that sponsor them. A minority of healthcare systems in the USA measure the impact of these programmes on organisational metrics such as staff turnover or cost savings. This systematic review sought to answer the question, 'What evidence exists that leadership and/or management development and training programs yield benefits for health care organizations?' These benefits could include return on investment, improved productivity/cohesion/teaming, or increased use of specific management skills (eg, strategic planning) that would directly benefit the organisation. Methods We followed Preferred Reporting Items for Systematic Reviews and Meta-Analyses guidelines to conduct a systematic review of the relevant literature. We conducted two searches in PubMed and one in ABI/Inform, a business literature database. All articles included for the study were further categorised according to their relevance for answering the research questions, using predefined criteria based on their methodology and reported findings.

Results Our search included 2462 studies, of which 55 met criteria for inclusion. We identified four potential organisation-level benefits to leadership and management training programmes: benefits to other staff (besides those who participate in the programmes), improved patient safety and satisfaction, tangible benefits from projects that were part of the programme and improved ability/confidence using leadership-related skills by programme participants. However, the research base on this topic is limited.

Conclusion Although this research identified potential benefits of leadership and management programmes at the organisation level, additional research is needed to make definitive conclusions about their impact.

\section{INTRODUCTION}

The topic of leadership and management development in healthcare, both for clinical and nonclinical leaders, has gained increasing attention in recent decades as healthcare systems face new challenges and complexities. ${ }^{12}$ For example, between April 2014 and March 2015, over 35000 people had enrolled in one of four programmes offered by the UK's National Health Service Leadership Academy. ${ }^{3}$ A survey in 2010 of 104 healthcare systems in the USA found that over $50 \%$ had some kind of executive leadership development programme. ${ }^{4}$

Leadership programmes for healthcare professionals can focus on a wide range of topics, including foundational knowledge (eg, healthcare economics, regulatory and compliance issues), execution of projects, managing people and transforming organisations. ${ }^{2}$ They can also take on a wide variety of formats, lengths and other design criteria. This breadth of topics and formats is unsurprising given the multiple levels of leadership needed in healthcare (team, organisational and national) and the different types of competencies and behaviours required for leadership. ${ }^{5}$

Evidence suggests that factors specific to an individual organisation, such as the management team (as opposed to industry and corporateparent effects), can account for up to one-third of the variation in its profitability. ${ }^{6}$ Further evidence also suggests that investment in human resource management more broadly can reduce turnover and improve profits. ${ }^{7}$

Therefore, as healthcare organisations invest in leadership and management development and training programmes, it is critical to understand the types of potential benefits from these programmes for the individual and for the sponsoring organisation. ${ }^{8}$ Healthcare organisations should have a clear understanding of the kinds of impact that they may expect to achieve from leadership and management development programmes in order to design them appropriately and assess their impact over time. Yet a minority of healthcare systems in the USA measure the impact of their programmes on organisational metrics such as turnover, cost savings or market share. ${ }^{4}$ Accordingly, this review aims to answer the research question: 'What evidence exists that leadership and/or management development and training programs yield benefits for health care organizations?'

To date, at least one systematic review has addressed a similar topic. Frich et $a l^{9}$ examined the impact of leadership development programmes for physicians on four outcomes: reactions to the programme, knowledge, behaviour/expertise and system results/performance. Frich et al found that 'physician leadership development programs are associated with increased self-assessed knowledge and expertise; however, few studies have examined outcomes at a system level' (p 656).

Our systematic review builds on this important work by Frich et al and differs from it in two critical ways. First, our research looks at leadership and management development programmes across all
To cite: Seidman G, Pascal L 2020:4:21-36. 
types of professionals working in healthcare, not just physicians. These could include nurse leaders, administrators, public health professionals and academics (ie, in academic medical centres). Second, our review aims to answer a more targeted question than Frich et al by specifically looking at the organisational benefits of these types of programmes. Given the investment required to undertake leadership development programmes and the importance of different types of professionals working in healthcare systems, this review can supplement the findings documented by Frich et al for healthcare administrators considering whether to undertake leadership or management development programmes.

\section{METHODS}

We conducted a systematic review consistent with Preferred Reporting Items for Systematic Reviews and Meta-Analyses guidelines. $^{10}$

\section{Search process and criteria}

This search relied on an internal protocol developed by GS in partnership with two librarians at Harvard University (one affiliated with Harvard Medical School and one affiliated with Harvard Business School). The protocol was not registered externally. We conducted two separate searches in PubMed and one in ABI/ Inform, a business literature database, on 5 January 2016 and a third search in PubMed in response to reviewer comments on 28 August 2017. Any references from these searches published before this date were eligible for inclusion. The earliest article that was included in this search was published in $1969 .{ }^{11}$ The search terms for the primary search in PubMed were as follows:

('Education, Medical, Continuing'[mesh] OR 'Staff Development'[Mesh] OR 'Education, Nursing, Continuing'[MeSH Terms] OR 'Leadership/education'[Mesh] OR education[tiab] OR training[tiab]) AND ('Leadership'[mesh] OR leadership[tiab]) AND ('Physician Executives'[Mesh] OR 'Nurse Administrators'[Mesh] OR 'Health Facility Administrators'[Mesh] OR executive*[tiab] OR administrator*[tiab] OR manager*) AND ('Program Evaluation' OR 'Organizational Objectives' [MeSH Terms] OR 'Cost Benefit Analysis'[mesh] OR evaluat*[tiab] OR cost benefit*[tiab])

We searched reference lists from literature reviews and other highly relevant papers identified during the database searches, including reference lists from all publications by one author (A McAlearney ${ }^{4} 12{ }^{13}$ ) whose work was highly pertinent for this review. We also reviewed any paper included in the Frich et al systematic review which had as its evaluation objective knowledge, behaviour/expertise (subjective or objective), or system results/performance (subjective or objective). ${ }^{9}$ (Papers included in Frich et al only evaluating participants' reactions to a leadership programme or subjective knowledge were excluded.) We also conducted consultations with managers focused on leadership development at three academic medical centres in Boston (Beth Israel Deaconess Medical Center, Brigham and Women's Hospital and Massachusetts General Hospital) and searched the websites of three top executive search firms (Korn Ferry, Boyden and Egon Zehnder), four management consulting firms (McKinsey, BCG, Bain and Deloitte) and the National Center for Healthcare Leadership for published literature on this topic.

\section{Study selection and eligibility criteria}

After conducting our search, all titles were reviewed for relevance. After excluding irrelevant titles, we read all abstracts and, when appropriate, full articles to determine both the relevance of the article for our research question and the availability of relevant data for inclusion. To be included in the review, the reference had to:

- Analyse or document effects of a leadership or management development programme to an organisation, such as return on investment (ROI), improved productivity/ cohesion/teaming, or increased use of specific management skills (eg, strategic planning) that would directly benefit the organisation.

- Report on a programme which trained executive, practitioner or management-level staff.

- Report on a programme which did not take place fulltime at a college or university (ie, a degree programme); programmes which engaged professionals working full-time but which also culminated in them receiving a degree (eg, a leadership programme for residents that also resulted in the completion of an Masters of Public Health degree) were not excluded.

- Focus on the healthcare/public health sectors.

- Be original research with a full article in English available (as opposed to literature reviews, editorials, commentaries, interviews, research abstracts, and so on). In cases where only a research abstract was available but the corresponding full article was not available, the abstract was excluded from our review.

It is worth noting that leadership is critical for supporting quality improvement (QI) initiatives, and leadership and management development programmes often include a component specifically focused on QI. ${ }^{14}$ That being said, not all QI strategies specifically require leadership or management development/training. For example, some strategies, such as provider reminder systems, involve more task or process-oriented changes to the organisation, rather than leadership or management training. ${ }^{15}$ Therefore, to maintain an appropriate scope which addressed our research question, we did not include a broader review of all types of QI initiatives.

\section{Data collection process}

To extract the data for this review, we piloted an Excel-based data collection tool that was used to capture the results, including the author, title, year, journal, abstract, training programme type, relevant outcome metric, outcome result and quality of article data for answering our research question. We categorised articles based on their relevance for answering our research question based on a combination of methodological approach, methodological quality and findings, using the following five categories and corresponding definitions:

- Articles with quantitative results

- High relevance: Articles which tested for statistical significance against a control group to evaluate effects on or benefits to the organisation. Effects/benefits were quantified using some methodology other than self-report (eg, peer review, third-party observer, cost savings, and so on).

- Medium relevance: Articles which used quantitative methods to identify effects on or benefits to the organisation but did not include measure of statistical significance against a control group. Benefits to the organisation quantified using some methodology other than selfreport (eg, peer review, third-party observer, cost savings, and so on).

- Low relevance: Articles which used quantitative methods based on self-report, with or without statistical significance against a control group, to determine effects on/ 
benefits to the organisation, OR article focused only on reports of increased skills which could be construed as benefitting the organisation (eg, managers' direct reports stating that their employees used conflict resolution skills more frequently) but which were not a direct measure of the organisation's performance.

- Null results: Articles whose methodology qualified as high or medium but found null results for benefits to the organisation.

- Articles with qualitative results: Articles which explicitly sought to identify benefits beyond those that accrued to programme participants, and which included interviews with individuals other than participants in the development programme, were included in this review. In other words, articles using a qualitative methodology with self-report only were excluded. Descriptive studies of programmes without a summary of benefits for the organisation were (eg, case studies) excluded.

Preliminary results were first presented at a workshop with representatives from leading healthcare institutions including Harvard T H Chan School of Public Health, Harvard Medical School, three affiliated academic medical centres and KPMG. Presenting these preliminary results in this forum allowed us to validate our findings and identify research articles that we had missed during the initial review.

\section{Risk of bias}

As with any systematic review, this research has the potential for several forms of bias. First, there is a risk that organisations are more likely to publish results that reflect well on their organisations or programmes, and they are unlikely to publish information with negative results. Organisations are unlikely to publish proprietary financial data relating to their programmes. In addition, evaluations that rely on self-report, which are common for collecting participants' feedback on training programmes, will have self-report bias. Accordingly, although studies with selfreport are important for understanding the total evidence base on this topic, they are considered low relevance for making final conclusions about the impact of leadership and management training programmes, as described earlier.

\section{RESULTS}

\section{Study selection and study characteristics}

Our search strategy identified 2462 articles for review. Of these, we excluded 2063 based on initial title/abstract review and included 399 for detailed review. Of these 399, we ultimately included 55 articles that met inclusion criteria. We excluded two articles that focused on leadership training but whose programmes also had a significant focus on clinical skills, which made disaggregating the impacts of the leadership training from the clinical training impossible. ${ }^{1617}$ Of these 55 articles, 5 had high relevance, 12 had medium relevance, 30 had low relevance, 2 quantitative articles had null results and 6 articles used qualitative methods relevant for answering our research question. Of the articles with high relevance or null results, only two used a randomised controlled trial design. ${ }^{18} 19$ See figure 1 for the flow chart of study selection for inclusion in the systematic review, and table 1 for the full list of studies included in the systematic review.

Of the 21 articles included in Frich et al, 12 met inclusion criteria for our study. Of the nine included in Frich et al that we excluded, four were excluded because the outcomes measured were not applicable to our research question (eg, programme participants' ratings of programme quality), and five were

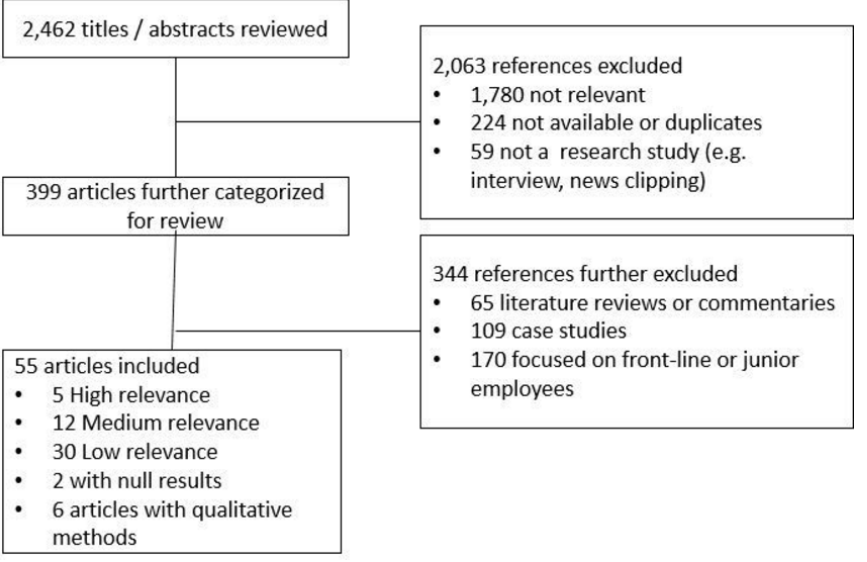

Figure 1 Flow chart of studies included in this review.

excluded because we were unable to find full copies of the articles after searching two academic libraries. ${ }^{20-22}$ The fact that only 12 of the 55 articles in our review were also included by Frich et al indicates that our search strategy achieved its goal of reviewing studies for a broader group of participants (eg, nurses and non-clinical managers).

\section{Synthesis of results}

The review found a wide range of types of programmes for leadership and management development and training, which included, among others: programmes specifically associated with QIs ${ }^{182}$; programmes focused on training women in leadership positions ${ }^{2425}$; trainings for professionals working in specific clinical specialties ${ }^{26}$ or public health programmes ${ }^{28}$; and programmes focused on multidisciplinary teams and cross-team communication. ${ }^{29}$ These programme types were not necessarily mutually exclusive, and many programmes had multiple training components or multiple intended outcomes.

A limited number of high-relevance articles have attempted to determine the benefits of leadership and management training programmes for organisations. Low-relevance articles tended to use self-report by individuals who participated in training programmes on their changes in leadership-related skills or competencies. While these self-reported improvements in leadership behaviours could translate into other benefits for the organisation (such as increased profits or improved retention of staff), it would be premature to draw any conclusions of this sort from the available literature.

Of the four high-relevance studies, two found statistically significant evidence of improved workplace communication and teaming, ${ }^{18} 29$ one found higher retention rates for women who participated in a career development programme ${ }^{30}$ and one found improved performance of workshop participants on management skills that impacted their teams (eg, assigning roles). ${ }^{31}$ Across all studies included in our review, four key areas emerged as potential benefits that an organisation might receive from a leadership/ management development or training programme. All findings reported below are from studies deemed to have high or mediumquality evidence unless otherwise specified. We also report here several miscellaneous positive effects and several null results.

1. Benefits to other staff in the organisation, such as increased staff support by leaders/managers or more effective teaming. This set of benefits had the greatest amount of evidence in the literature reviewed. Benefits to other staff took many different forms, which are not mutually exclusive and which may actually reinforce each other. For example, after 
Original research

Table 1 Studies included in systematic review

\begin{tabular}{|c|c|c|c|c|c|c|c|}
\hline Author & Title & Year & Journal & Relevance & Programme type & Outcome metric & Outcome result \\
\hline \multicolumn{8}{|l|}{ High relevance } \\
\hline Boyle and Kochinda ${ }^{29}$ & $\begin{array}{l}\text { Enhancing } \\
\text { collaborative } \\
\text { communication of } \\
\text { nurse and physician } \\
\text { leadership in two } \\
\text { intensive care units }\end{array}$ & 2004 & J Nurs Adm & High & $\begin{array}{l}\text { Intervention to } \\
\text { enhance collaborative } \\
\text { communication among } \\
\text { nurse and physician } \\
\text { leaders in two diverse } \\
\text { ICUs. }\end{array}$ & $\begin{array}{l}\text { Changes in unit } \\
\text { staff perceptions } \\
\text { on collaborative } \\
\text { communication } \\
\text { before and after } \\
\text { interventions; } \\
\text { changes in unit staff } \\
\text { perceptions of ICU } \\
\text { outcomes. }\end{array}$ & $\begin{array}{l}\text { Staff perceived } \\
\text { improvement } \\
\text { on } 5 \text { dimensions } \\
\text { of collaborative } \\
\text { communication } \\
\text { measured, with } \\
\text { statistically significant } \\
\text { improvement (p<0.05) } \\
\text { for problem solving } \\
\text { between groups and } \\
\text { nursing leadership; } \\
\text { staff perceived } \\
\text { improvements on ICU } \\
\text { outcomes that were not } \\
\text { statistically significant. }\end{array}$ \\
\hline
\end{tabular}

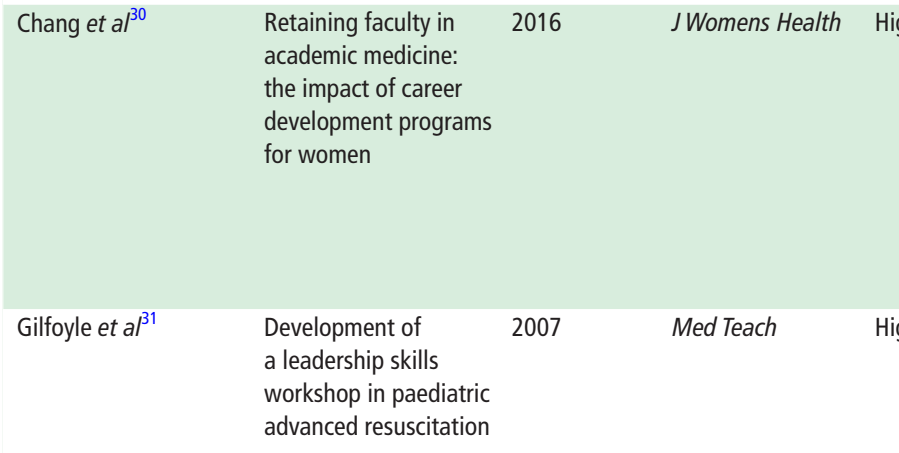

\begin{tabular}{|c|c|c|c|}
\hline Jeon et $a l^{18}$ & $\begin{array}{l}\text { Cluster randomized } \\
\text { controlled trial of an } \\
\text { aged care specific } \\
\text { leadership and } \\
\text { management program } \\
\text { to improve work } \\
\text { environment, staff } \\
\text { turnover, and care } \\
\text { quality }\end{array}$ & 2015 & $\begin{array}{l}\text { JAm Med Dir } \\
\text { Assoc }\end{array}$ \\
\hline Shirazi et al ${ }^{19}$ & $\begin{array}{l}\text { The effects of } \\
\text { intervention based on } \\
\text { supportive leadership } \\
\text { behaviour on Iranian } \\
\text { nursing leadership } \\
\text { performance: a } \\
\text { randomized controlled }\end{array}$ & 2016 & J Nurs Manag \\
\hline
\end{tabular}

tria

\section{Medium relevance}

Anonymous $^{40}$

Assessment tool helps 2006

hospital conquer

challenges
Evaluation of three Retention rates of CDP

Career Development women compared

Programs (CDP) aiming with non-CDP women

to support women and CDP men.

faculty at academic

medical centres,

including by preparing

them for leadership

roles.

Workshop designed

to train residents in

leadership specifically

relevant to patient

resuscitation.

leadership skills

(assigning roles,

Performance on a Workshop participants

20-item checklist that scored significantly

evaluated specific better on checklists

6 months after

limitations of team,

communication

and overall team

atmosphere);

self-assessment

of confidence in

leadership role.

Evaluation of the

Clinical Leadership

in Aged Care (CLiAC)

programme in

Australian aged care

services.

Measures of

workplace

environment

behaviours using the

Work Environment

Scale-R (WED-R)

and the Multifactor

Leadership

Questionnaire (MLQ)

Rater Form

workshop compared

with controls $(p<0.01)$;

participants self-

reported statistically

significant increases in

their competencies.

Demonstration of

Workshop on

supportive leadership

behaviour for head

supportive leadership

behaviours, as

reported by head

nurses' subordinates.

Statistically significant improvement on

transformation

leadership, reduction in transactional leadership and passive avoidant

behaviour, and improved outcomes

of leadership (extra

effort, effectiveness and satisfaction).

Statistically significant

increase in supportive leadership behaviours $(p<0.0001)$ among workshop participants compared with control group.

\begin{tabular}{|c|c|c|}
\hline $\begin{array}{l}\text { Three-pronged } \\
\text { approach to improving } \\
\text { leadership in a hospital, } \\
\text { including top-down } \\
\text { dissemination of } \\
\text { training, annual } \\
\text { leadership forums and } \\
\text { the use of personality- } \\
\text { type tests to enhance } \\
\text { communication. }\end{array}$ & $\begin{array}{l}\text { Improvement on } \\
\text { patient satisfaction } \\
\text { scores across } 7 \\
\text { metrics, such as } \\
\text { 'nurses took time to } \\
\text { listen' and 'doctor's } \\
\text { concern for comfort'. }\end{array}$ & $\begin{array}{l}\text { Per cent of patients } \\
\text { reporting positive } \\
\text { experience in creased } \\
4.5 \%-9.0 \% \text { across } \\
\text { seven different metrics. }\end{array}$ \\
\hline
\end{tabular}




\begin{tabular}{|c|c|c|c|c|c|c|c|}
\hline Author & Title & Year & Journal & Relevance & Programme type & Outcome metric & Outcome result \\
\hline Dannels et a $\left.\right|^{25}$ & $\begin{array}{l}\text { Medical school } \\
\text { deans' perceptions of } \\
\text { organizational climate: } \\
\text { useful indicators } \\
\text { for advancement } \\
\text { of women faculty } \\
\text { and evaluation of a } \\
\text { leadership program's } \\
\text { impact }\end{array}$ & 2009 & Acad Med & Medium & $\begin{array}{l}\text { Survey of medical } \\
\text { school deans' } \\
\text { perceptions of ELAM } \\
\text { and its impacts. }\end{array}$ & $\begin{array}{l}\text { Perceptions of ELAM } \\
\text { programme, including } \\
\text { agreement with the } \\
\text { statement, 'I am } \\
\text { confident that our } \\
\text { ELAM alumnae are } \\
\text { more likely to stay at } \\
\text { our institution than } \\
\text { other women faculty } \\
\text { here.' }\end{array}$ & $\begin{array}{l}\text { Average score of } 5.11 \\
\text { on Likert scale of } 7 \\
\text { (with } 7 \text { indicating } \\
\text { 'strongly agree'). }\end{array}$ \\
\hline Foster et $a l^{23}$ & $\begin{array}{l}\text { Residency education, } \\
\text { preventive medicine, } \\
\text { and population health } \\
\text { care improvement: the } \\
\text { Dartmouth-Hitchcock } \\
\text { leadership preventive } \\
\text { medicine approach }\end{array}$ & 2008 & Acad Med & Medium & $\begin{array}{l}\text { Leadership Preventive } \\
\text { Medicine residency, } \\
\text { which focuses on } \\
\text { leadership of small } \\
\text { systems in healthcare, } \\
\text { measurement of illness } \\
\text { burden in individuals } \\
\text { and populations, } \\
\text { measurement of the } \\
\text { outcomes of health } \\
\text { service interventions, } \\
\text { leadership of change } \\
\text { for improvement of } \\
\text { quality, value and } \\
\text { safety of healthcare } \\
\text { of individuals and } \\
\text { populations, and } \\
\text { reflection on personal } \\
\text { professional practice } \\
\text { enabling personal } \\
\text { and professional } \\
\text { development. }\end{array}$ & $\begin{array}{l}\text { Results of the } \\
\text { participant-led } \\
\text { practicum projects. }\end{array}$ & $\begin{array}{l}\text { Of the } 12 \text { graduates } \\
\text { of the programme, the } \\
\text { article reports on } 8 \\
\text { which achieved positive } \\
\text { results (other } 4 \text { not } \\
\text { reported on). }\end{array}$ \\
\hline Green and Plsek ${ }^{43}$ & $\begin{array}{l}\text { Coaching and } \\
\text { leadership for the } \\
\text { diffusion of innovation } \\
\text { in health care: a } \\
\text { different type of } \\
\text { multi-organization } \\
\text { improvement } \\
\text { collaborative }\end{array}$ & 2002 & $\begin{array}{l}\text { Journal on Quality } \\
\text { Improvement }\end{array}$ & Medium & $\begin{array}{l}\text { Coaching and } \\
\text { leadership initiative to } \\
\text { develop new methods } \\
\text { of collaborating for } \\
\text { organisational learning } \\
\text { of best practices, with a } \\
\text { focus on generalisable } \\
\text { change and deliberate } \\
\text { leadership support for } \\
\text { deployment, diffusion } \\
\text { and sustainability. }\end{array}$ & $\begin{array}{l}\text { Improvement } \\
\text { on management } \\
\text { indicators for various } \\
\text { topics (eg, reduction } \\
\text { time from abnormal } \\
\text { mammogram } \\
\text { findings to definitive } \\
\text { diagnosis, reduce } \\
\text { patient registration } \\
\text { time, improvement in } \\
\text { patient experience/ } \\
\text { self-reported pain, and } \\
\text { so on). }\end{array}$ & $\begin{array}{l}\text { Improvement across } \\
\text { multiple management } \\
\text { and performance } \\
\text { indicators. }\end{array}$ \\
\hline Haseman et $\left.a\right|^{39}$ & $\begin{array}{l}\text { Practising inspired } \\
\text { leadership: the use } \\
\text { of applied theatre } \\
\text { 'prophetical' in the } \\
\text { executive Leadership } \\
\text { Development Program } \\
\text { for Queensland Health }\end{array}$ & 2009 & Aust Health Rev & Medium & $\begin{array}{l}\text { Leadership Program } \\
\text { including residential } \\
\text { workshop for } \\
\text { executives, non- } \\
\text { residential workshop } \\
\text { for managers and } \\
\text { supervisors, } 360^{\circ} \\
\text { feedback, executive } \\
\text { coaching, web-based } \\
\text { support and online } \\
\text { learning modules. }\end{array}$ & $\begin{array}{l}\text { Changes in formal } \\
\text { grievances, consumer } \\
\text { complaints, } \\
\text { absenteeism, retention } \\
\text { of staff and other } \\
\text { metrics. }\end{array}$ & $\begin{array}{l}56 \% \text { reduction in } \\
\text { formal grievances; } \\
28 \% \text { reduction in } \\
\text { consumer complaints; } \\
14 \% \text { improvement } \\
\text { in absenteeism; } 17 \% \\
\text { improvement in } \\
\text { retention. }\end{array}$ \\
\hline Hultman et $a^{\beta 2}$ & $\begin{array}{l}\text { Sometimes you can't } \\
\text { make it on your } \\
\text { own: the impact of } \\
\text { a professionalism } \\
\text { curriculum on the } \\
\text { attitudes, knowledge, } \\
\text { and behaviors of } \\
\text { an academic plastic } \\
\text { surgery practice }\end{array}$ & 2013 & J Surg Res & Medium & $\begin{array}{l}\text { Course on } \\
\text { professionalism in } \\
\text { plastic surgery for } \\
\text { professionals of } \\
\text { all levels (faculty, } \\
\text { residents, nurses and } \\
\text { medical students). }\end{array}$ & $\begin{array}{l}\text { Number of } \\
\text { unprofessional } \\
\text { behaviours requiring } \\
\text { involvement by senior } \\
\text { administrators during } \\
\text { the } 6 \text { months before } \\
\text { and after the course. }\end{array}$ & $\begin{array}{l}\text { Number of events } \\
\text { reduced from } 12 \text { to } 3 .\end{array}$ \\
\hline
\end{tabular}


Original research

\begin{tabular}{|c|c|c|c|c|c|c|c|}
\hline Author & Title & Year & Journal & Relevance & Programme type & Outcome metric & Outcome result \\
\hline Levine et $a^{/ 42}$ & $\begin{array}{l}\text { Chief resident } \\
\text { immersion training } \\
\text { in the care of older } \\
\text { adults: an innovative } \\
\text { interspecialty education } \\
\text { and leadership } \\
\text { intervention }\end{array}$ & 2008 & JAm Geriat Soc & Medium & $\begin{array}{l}\text { Two-day Chief } \\
\text { Resident Immersion } \\
\text { Training programme } \\
\text { formally preparing } \\
\text { chief residents for } \\
\text { their role; programme } \\
\text { required chief residents } \\
\text { to develop an action } \\
\text { project focused on } \\
\text { the management of } \\
\text { complex older patients } \\
\text { over the following year. }\end{array}$ & $\begin{array}{l}\text { Per cent of participants } \\
\text { completing their } \\
\text { action projects (paper } \\
\text { also reports self- } \\
\text { report data related } \\
\text { to role performance; } \\
\text { these data are not } \\
\text { summarised here). }\end{array}$ & $\begin{array}{l}60 \% \text { of chief residents } \\
\text { had completed at least } \\
\text { half of their action } \\
\text { project, and } 18 \% \text { of } \\
\text { chief residents had } \\
\text { completed their entire } \\
\text { project. }\end{array}$ \\
\hline Mansour et al/4 & $\begin{array}{l}\text { Scaling up proven } \\
\text { public health } \\
\text { interventions through } \\
\text { a locally owned and } \\
\text { sustained leadership } \\
\text { development } \\
\text { programme in rural } \\
\text { Upper Egypt }\end{array}$ & 2010 & $\begin{array}{l}\text { Hum Resour } \\
\text { Health }\end{array}$ & Medium & $\begin{array}{l}\text { Leadership } \\
\text { Development Program } \\
\text { in three districts } \\
\text { in Egypt aimed to } \\
\text { improve health } \\
\text { services by increasing } \\
\text { managers' ability to } \\
\text { create high-performing } \\
\text { teams and lead them } \\
\text { to achieve results. }\end{array}$ & $\begin{array}{l}\text { Achievement of teams' } \\
\text { intended population } \\
\text { health goals. }\end{array}$ & $\begin{array}{l}\text { Eight of the } 10 \text { health } \\
\text { teams achieved } 95 \% \\
\text { of more of their } \\
\text { desired results, and } \\
\text { family planning visits } \\
\text { increased by } 20 \%-68 \% \\
\text { in the three districts } \\
\text { where the programme } \\
\text { took place. }\end{array}$ \\
\hline Orton et al ${ }^{41}$ & $\begin{array}{l}\text { Management } \\
\text { academy for public } \\
\text { health: creating } \\
\text { entrepreneurial } \\
\text { managers }\end{array}$ & 2007 & Am J Public Health & Medium & $\begin{array}{l}\text { Trainings for teams, } \\
\text { often from local public } \\
\text { health agencies, to } \\
\text { conduct an action- } \\
\text { learning project where } \\
\text { teams develop a public } \\
\text { health business plan } \\
\text { for a sustainable new } \\
\text { programme. }\end{array}$ & $\begin{array}{l}\text { Per cent of plans } \\
\text { fully implemented, } \\
\text { implemented midway, } \\
\text { or at initial stages } \\
\text { of implementation; } \\
\text { per cent of team } \\
\text { generating revenue } \\
\text { after } 2 \text { years. }\end{array}$ & $\begin{array}{l}22 \%, 17 \% \text { and } 15 \% \text {, } \\
\text { respectively; } 38 \% \\
\text { generating revenue } \\
\text { (28 teams generating a } \\
\text { total of } \$ 4 \text { million). }\end{array}$ \\
\hline $\begin{array}{l}\text { Tumerman and } \\
\text { Carlson }^{36}\end{array}$ & $\begin{array}{l}\text { Increasing medical } \\
\text { team cohesion and } \\
\text { leadership behaviors } \\
\text { using a } 360 \text { degree } \\
\text { evaluation process }\end{array}$ & 2012 & WMJ & Medium & $\begin{array}{l}360^{\circ} \text { evaluation } \\
\text { process. }\end{array}$ & $\begin{array}{l}\text { Per cent of staff } \\
\text { seeing changes } \\
\text { for the better in } \\
\text { physician behaviours } \\
\text { in connection to the } \\
\text { process (willingness } \\
\text { to change, respect, } \\
\text { quality of care, support } \\
\text { of team members, } \\
\text { compassion, efficiency, } \\
\text { teamwork). }\end{array}$ & $\begin{array}{l}\text { Per cent of staff seeing } \\
\text { improvements ranged } \\
\text { from } 17 \% \text { for quality of } \\
\text { care to } 63 \% \text { for respect } \\
\text { and teamwork. }\end{array}$ \\
\hline West et $a l^{35}$ & $\begin{array}{l}\text { Evaluation of a clinical } \\
\text { leadership initiative }\end{array}$ & 2004 & Nurs Stand & Medium & $\begin{array}{l}\text { System of mentorship, } \\
\text { education and training } \\
\text { to address issues with } \\
\text { treating mental health } \\
\text { issues and care of older } \\
\text { people. }\end{array}$ & $\begin{array}{l}\text { Multiple measures } \\
\text { by participants' } \\
\text { colleagues, including } \\
\text { changes in direct } \\
\text { care management, } \\
\text { decision-making, } \\
\text { communication } \\
\text { processes, clinical } \\
\text { nursing care, reporting } \\
\text { and evaluation, and } \\
\text { support strategies and } \\
\text { processes. }\end{array}$ & $\begin{array}{l}\text { Majority of results } \\
\text { suggested that all skills } \\
\text { improved. }\end{array}$ \\
\hline
\end{tabular}

Low relevance 


\begin{tabular}{|c|c|c|c|c|c|c|c|}
\hline Author & Title & Year & Journal & Relevance & Programme type & Outcome metric & Outcome result \\
\hline $\begin{array}{l}\text { Anderson and Lavoie- } \\
\text { Tremblay }{ }^{65}\end{array}$ & $\begin{array}{l}\text { Evaluation of the } \\
\text { Executive Training for } \\
\text { Research Application } \\
\text { (EXTRA) program: } \\
\text { design and early } \\
\text { findings }\end{array}$ & 2008 & Healthc Policy & Low & $\begin{array}{l}\text { Programme 'to support } \\
\text { evidence-informed } \\
\text { decision-making in } \\
\text { the organization, } \\
\text { management and } \\
\text { delivery of health } \\
\text { services through } \\
\text { funding research, } \\
\text { building capacity } \\
\text { and transferring } \\
\text { knowledge' for health } \\
\text { service professionals } \\
\text { in senior management } \\
\text { positions. }\end{array}$ & $\begin{array}{l}\text { Per cent of participants } \\
\text { who believed their } \\
\text { knowledge of } \\
\text { change management } \\
\text { was 'very good' or } \\
\text { 'excellent'. }\end{array}$ & $\begin{array}{l}\text { Increase from } 37 \% \\
\text { before the programme } \\
\text { to } 95 \% 2 \text { years into the } \\
\text { programme. }\end{array}$ \\
\hline Bowles and Bowles ${ }^{46}$ & $\begin{array}{l}\text { A comparative study } \\
\text { of transformational } \\
\text { leadership in nursing } \\
\text { development units and } \\
\text { conventional clinical } \\
\text { settings }\end{array}$ & 2000 & J Nurs Manag & Low & $\begin{array}{l}\text { Nursing development } \\
\text { units (NDU) to serve } \\
\text { as centres of nursing } \\
\text { excellence, innovation } \\
\text { and leadership } \\
\text { development. }\end{array}$ & $\begin{array}{l}\text { Total leadership score } \\
\text { on Leadership Practice } \\
\text { Inventory (LPI) by } \\
\text { observers. }\end{array}$ & $\begin{array}{l}8 \% \text { higher score on } \\
\text { LPI among NDU nurses } \\
\text { than non-NDU nurses. }\end{array}$ \\
\hline Brandon and Mullan ${ }^{49}$ & $\begin{array}{l}\text { Teaching medical } \\
\text { management and } \\
\text { operations engineering } \\
\text { for systems-based } \\
\text { practice to radiology }\end{array}$ & 2013 & Acad Radiol & Low & $\begin{array}{l}\text { Programme to enhance } \\
\text { resident's knowledge } \\
\text { and ability to apply } \\
\text { concepts from medical } \\
\text { management and } \\
\text { industrial/operations } \\
\text { engineering to } \\
\text { radiology practice. }\end{array}$ & $\begin{array}{l}\text { Knowledge of seven } \\
\text { domains taught in the } \\
\text { programme. }\end{array}$ & $\begin{array}{l}\text { Participants showed } \\
\text { statistically significant } \\
\text { improvement on all } \\
\text { seven domains tested. }\end{array}$ \\
\hline Brinkert $^{50}$ & $\begin{array}{l}\text { Conflict coaching } \\
\text { training for nurse } \\
\text { managers: a case } \\
\text { study of a two-hospital } \\
\text { health system }\end{array}$ & 2011 & J Nurs Manag & Low & $\begin{array}{l}\text { Training of nurse } \\
\text { managers as conflict } \\
\text { coaches to improve } \\
\text { conflict understanding, } \\
\text { interaction strategies } \\
\text { and/or interaction } \\
\text { skills. }\end{array}$ & $\begin{array}{l}\text { Response to question: } \\
\text { To what degree have } \\
\text { your goals for the } \\
\text { conflict coaching } \\
\text { training programme } \\
\text { been met? }\end{array}$ & $\begin{array}{l}95 \% \text { reporting high } \\
\text { or moderately high } \\
\text { at } 3 \text { and } 6 \text { months' } \\
\text { follow-up. }\end{array}$ \\
\hline Burns and Papa ${ }^{51}$ & $\begin{array}{l}\text { Self-reported changes } \\
\text { in nurse manager } \\
\text { proficiency resulting } \\
\text { from participation } \\
\text { in the Rising Star } \\
\text { Leadership Program }\end{array}$ & 2008 & Pa Nurse & Low & $\begin{array}{l}\text { Three-day programme } \\
\text { to assist nurses to } \\
\text { improve the quality } \\
\text { of their individual } \\
\text { work environments } \\
\text { and units, advocate } \\
\text { for health employee } \\
\text { lifestyles, become } \\
\text { vigilant about patient } \\
\text { safety and develop } \\
\text { oneself and develop } \\
\text { others. }\end{array}$ & $\begin{array}{l}\text { Per cent of nurse } \\
\text { managers rating } \\
\text { training as useful } \\
\text { for their work } 3 \text { and } \\
6 \text { months after the } \\
\text { training (response of } \\
\text { 'high' or 'moderately } \\
\text { high'). }\end{array}$ & $95 \%$ at 3 and 6 months. \\
\hline Cooper $^{66}$ & $\begin{array}{l}\text { An evaluation of the } \\
\text { Leading an Empowered } \\
\text { Organisation } \\
\text { programme }\end{array}$ & 2003 & Nurs Stand & Low & $\begin{array}{l}\text { NHS leadership } \\
\text { development } \\
\text { programme Leading } \\
\text { an Empowered } \\
\text { Organisation (LEO). }\end{array}$ & $\begin{array}{l}\text { Change in self-rating } \\
\text { of performance on five } \\
\text { leadership behaviours } \\
\text { (articulating the } \\
\text { goal, maintaining } \\
\text { organisational } \\
\text { objectives, exhibiting } \\
\text { trust, presenting } \\
\text { challenging } \\
\text { opportunities and } \\
\text { getting outside } \\
\text { support) before and } \\
\text { after the programme. }\end{array}$ & $\begin{array}{l}P<0.05 \text { for four out of } \\
\text { five behaviours, and } \\
p=0.052 \text { for exhibiting } \\
\text { trust. }\end{array}$ \\
\hline Crites and Schuster ${ }^{26}$ & $\begin{array}{l}\text { A preliminary report } \\
\text { of an educational } \\
\text { intervention in practice } \\
\text { management }\end{array}$ & 2004 & $\begin{array}{l}\text { BMC Medical } \\
\text { Education }\end{array}$ & Low & $\begin{array}{l}\text { Exploratory study on a } \\
\text { practice management } \\
\text { curriculum for primary } \\
\text { care residents. }\end{array}$ & $\begin{array}{l}\text { Practice knowledge } \\
\text { on } 12 \text { management } \\
\text { topics, including } \\
\text { revenue management, } \\
\text { dynamics of group } \\
\text { practice and risk } \\
\text { management. }\end{array}$ & $\begin{array}{l}\text { Mean correct score on } \\
\text { the practice knowledge } \\
\text { test increased } \\
\text { from } 71 \% \text { before } \\
\text { participating in the } \\
\text { curriculum to } 91 \% \text { after } \\
\text { the curriculum. }\end{array}$ \\
\hline
\end{tabular}

Continued 
Original research

\begin{tabular}{|c|c|c|c|c|}
\hline Author & Title & Year & Journal & Relevance \\
\hline Dannels et $a^{52}$ & $\begin{array}{l}\text { Evaluating a } \\
\text { leadership program: } \\
\text { a comparative, } \\
\text { longitudinal study } \\
\text { to assess the impact } \\
\text { of the Executive } \\
\text { Leadership in Academic } \\
\text { Medicine (ELAM) } \\
\text { program for women }\end{array}$ & 2008 & Acad Med & Low \\
\hline
\end{tabular}

\begin{tabular}{|c|c|c|c|c|c|c|c|}
\hline Day et $\left.a\right|^{27}$ & $\begin{array}{l}\text { Effectiveness of the } \\
\text { AAOS leadership } \\
\text { fellows program for } \\
\text { orthopaedic surgeons }\end{array}$ & 2010 & $\begin{array}{l}\text { The Journal of } \\
\text { Bone \& Joint } \\
\text { Surgery }\end{array}$ & Low & $\begin{array}{l}\text { One-year programme } \\
\text { designed to train young } \\
\text { orthopaedic surgeons } \\
\text { to become future } \\
\text { leaders in orthopaedics. }\end{array}$ & $\begin{array}{l}\text { Comparison of self- } \\
\text { reported confidence } \\
\text { on knowledge of } \\
\text { theory, environmental } \\
\text { scanning, financial } \\
\text { management, } \\
\text { communication skills, } \\
\text { conflict management, } \\
\text { diversity competence, } \\
\text { tolerance for demands } \\
\text { of leadership and } \\
\text { leadership positioning } \\
\text { between programme } \\
\text { participants and } \\
\text { rejected applicants. }\end{array}$ & $\begin{array}{l}\text { Higher confidence by } \\
\text { programme participants } \\
\text { on all dimensions } \\
\text { except financial } \\
\text { management, with } \\
\text { statistically significant } \\
\text { differences ( } p<0.05 \text { ) for } \\
\text { knowledge of theory, } \\
\text { tolerance for demands } \\
\text { of leadership and } \\
\text { leadership positioning. }\end{array}$ \\
\hline Duygulu and Kublay ${ }^{33}$ & $\begin{array}{l}\text { Transformational } \\
\text { leadership training } \\
\text { programme for charge } \\
\text { nurses }\end{array}$ & 2011 & JAdv Nurs & Low & $\begin{array}{l}\text { Transformational } \\
\text { leadership training } \\
\text { programme on } \\
\text { unit charge nurses' } \\
\text { leadership practices. }\end{array}$ & $\begin{array}{l}\text { Scores on LPI for five } \\
\text { traits (model the way, } \\
\text { inspire a shared vision, } \\
\text { challenge the process, } \\
\text { enabling others to act } \\
\text { and encourage the } \\
\text { heart) over the course } \\
\text { of four evaluations by } \\
\text { observers (colleagues). }\end{array}$ & $\begin{array}{l}\text { Nurses showed } \\
\text { statistically significant } \\
\text { improvement }(p=0.001) \\
\text { for all five traits. }\end{array}$ \\
\hline Edler et $a l^{67}$ & $\begin{array}{l}\text { Leadership lessons } \\
\text { from military education } \\
\text { for postgraduate } \\
\text { medical curricular } \\
\text { improvement }\end{array}$ & 2010 & $\begin{array}{l}\text { The Clinical } \\
\text { Teacher }\end{array}$ & Low & $\begin{array}{l}\text { Leadership Education } \\
\text { and Development } \\
\text { Program for paediatric } \\
\text { anaesthesia residents. }\end{array}$ & $\begin{array}{l}\text { 'Leadership } \\
\text { evaluation' of } \\
\text { residents by faculty } \\
\text { (scored from } 1 \text { to 9). }\end{array}$ & $\begin{array}{l}\text { Preintervention score } \\
6.8 ; \text { postintervention } \\
\text { score } 7.6(p<0.05)\end{array}$ \\
\hline Fiset et $\left.a\right|^{59}$ & $\begin{array}{l}\text { Clinical nursing } \\
\text { leadership education } \\
\text { in long-term care: } \\
\text { intervention design and } \\
\text { evaluation }\end{array}$ & 2017 & J Gerontol Nurs & Low & $\begin{array}{l}\text { Targeted intervention } \\
\text { on leadership } \\
\text { education for RNs, } \\
\text { registered practical } \\
\text { nurses and nursing } \\
\text { administrators. }\end{array}$ & $\begin{array}{l}\text { Self-reported } \\
\text { perceptions of } \\
\text { improvement on } \\
\text { various competencies, } \\
\text { such as 'self- } \\
\text { awareness and } \\
\text { personal insight' } \\
\text { and 'ability to give } \\
\text { feedback to others' in } \\
\text { survey } 3 \text { months after } \\
\text { intervention. }\end{array}$ & $\begin{array}{l}\text { All nurses agreed that } \\
\text { they had improved } \\
\text { along all dimensions } \\
\text { measured. }\end{array}$ \\
\hline
\end{tabular}


Original research

\begin{tabular}{|c|c|c|c|c|c|c|c|}
\hline Author & Title & Year & Journal & Relevance & Programme type & Outcome metric & Outcome result \\
\hline Hanna et $\left.a\right|^{54}$ & $\begin{array}{l}\text { Training future } \\
\text { surgeons for } \\
\text { management roles: } \\
\text { the resident-surgeon- } \\
\text { manager conference }\end{array}$ & 2012 & Arch Surg & Low & $\begin{array}{l}\text { 1-day management } \\
\text { seminar for senior } \\
\text { surgical residents. }\end{array}$ & $\begin{array}{l}\text { Self-report of } \\
\text { competence levels } \\
\text { for nine managerial } \\
\text { skills required for } \\
\text { efficient management } \\
\text { of a surgical service } \\
\text { or practice (\% rating } \\
\text { themselves 'Good' or } \\
\text { 'Excellent'). }\end{array}$ & $\begin{array}{l}\text { Statistically significant } \\
\text { improvement on } 7 \text { of } \\
9 \text { skills. }\end{array}$ \\
\hline Hartley and Garrett ${ }^{60}$ & $\begin{array}{l}\text { Impact of a } \\
\text { management } \\
\text { assessment centre in } \\
\text { developing proficient } \\
\text { health managers }\end{array}$ & 1997 & Aust Health Rev & Low & $\begin{array}{l}\text { Australian } \\
\text { Management } \\
\text { Competencies } \\
\text { Assessment Centre, } \\
\text { which assesses } \\
\text { participants on } \\
10 \text { leadership/ } \\
\text { management } \\
\text { dimensions and allows } \\
\text { them practice skills in } \\
\text { those dimensions. }\end{array}$ & $\begin{array}{l}\text { Self-report by } \\
\text { programme } \\
\text { participants on } \\
\text { management } \\
\text { competencies, use } \\
\text { of a professional } \\
\text { development plan } \\
\text { and use of continuing } \\
\text { professional } \\
\text { education, compared } \\
\text { with non-programme } \\
\text { participants. }\end{array}$ & $\begin{array}{l}\text { Programme participant } \\
\text { self-rated high on four } \\
\text { dimensions: leadership, } \\
\text { achievement, } \\
\text { strategic planning and } \\
\text { innovation }(p<0.05) \text {, } \\
\text { completed more work } \\
\text { using their personal } \\
\text { development plan } \\
\text { ( } p<0.05) \text {, and accessed } \\
\text { more continuing } \\
\text { education resources } \\
(p<0.05) \text {. }\end{array}$ \\
\hline Korschun et a/ ${ }^{68}$ & $\begin{array}{l}\text { Realizing the } \\
\text { vision of leadership } \\
\text { development in an } \\
\text { academic health } \\
\text { center: the Woodruff } \\
\text { Leadership Academy }\end{array}$ & 2007 & $\begin{array}{l}\text { Academic } \\
\text { Medicine }\end{array}$ & Low & $\begin{array}{l}\text { Leadership academy } \\
\text { including physicians, } \\
\text { PhD faculty, academic } \\
\text { administrators and } \\
\text { other staff focused on } \\
\text { developing leadership } \\
\text { skills relevant to the } \\
\text { Woodruff Health } \\
\text { Sciences Center } \\
\text { (WHSC). }\end{array}$ & $\begin{array}{l}\text { Self-report in response } \\
\text { to various questions } \\
\text { about the impact } \\
\text { of the leadership } \\
\text { academy. }\end{array}$ & $\begin{array}{l}\text { Select results: } 98 \% \text { of } \\
\text { participants agreed or } \\
\text { strongly agreed that } \\
\text { the academy increased } \\
\text { their commitment to } \\
\text { and support of the } \\
\text { vision and strategies } \\
\text { of WHSC; } 96 \% \text { of } \\
\text { participants strongly } \\
\text { agreed, agreed, or } \\
\text { slightly agreed that } \\
\text { participation in the } \\
\text { academy made the } \\
\text { more likely to stay at } \\
\text { WHSC. }\end{array}$ \\
\hline Krejci and Malin ${ }^{55}$ & $\begin{array}{l}\text { Impact of leadership } \\
\text { development on } \\
\text { competencies }\end{array}$ & 1997 & Nurs Econ & Low & $\begin{array}{l}\text { Leadership programme } \\
\text { designed to train nurse } \\
\text { managers to improve } \\
\text { outcomes in a cost- } \\
\text { effective manner. }\end{array}$ & $\begin{array}{l}\text { Self-reported ability } \\
\text { on } 12 \text { competencies, } \\
\text { including change, } \\
\text { communication and } \\
\text { systems thinking. }\end{array}$ & $\begin{array}{l}\text { Statistically significant } \\
(p<0.01) \text { improvement } \\
\text { on self-report ability for } \\
\text { all } 12 \text { competencies. }\end{array}$ \\
\hline Leslie et $a l^{61}$ & $\begin{array}{l}\text { Training young } \\
\text { paediatricians as } \\
\text { leaders for the 21st } \\
\text { century }\end{array}$ & 2005 & Pediatrics & Low & $\begin{array}{l}\text { Training programme for } \\
\text { young paediatricians } \\
\text { focused on self- } \\
\text { management skills, } \\
\text { systems management } \\
\text { skills and leadership } \\
\text { competencies within } \\
\text { the context of a team. }\end{array}$ & $\begin{array}{l}\text { Self-reported } \\
\text { competencies on } \\
\text { taught domains } \\
\text { and achievement } \\
\text { of personal goals in } \\
\text { one or more of the } \\
\text { domains. }\end{array}$ & $\begin{array}{l}\text { Statistically significant } \\
\text { increase in self-rated } \\
\text { performance on all } \\
20 \text { competencies } \\
\text { measured; } 87 \% \text { of } \\
\text { respondents reported } \\
\text { that they had at least } \\
\text { partially achieved their } \\
\text { goal. }\end{array}$ \\
\hline LoPresti et a ${ }^{48}$ & $\begin{array}{l}\text { Using a simulated } \\
\text { practice to improve } \\
\text { practice management } \\
\text { learning }\end{array}$ & 2009 & Family Medicine & Low & $\begin{array}{l}\text { 'Simulated practice' } \\
\text { with } 20 \text { modules } \\
\text { on specific practice } \\
\text { management tasks for } \\
\text { residents. }\end{array}$ & $\begin{array}{l}\text { Pretest/post-test } \\
\text { comparison (between- } \\
\text { group compared with } \\
\text { control and within- } \\
\text { group analysis) on a } \\
\text { practice management } \\
\text { examination. }\end{array}$ & $\begin{array}{l}\text { Programme participant } \\
\text { showed better } \\
\text { performance on } \\
\text { examination compared } \\
\text { with controls }(\mathrm{p}=0.006) \\
\text { and in within-group } \\
\text { pretest/post-test } \\
\text { analysis }(\mathrm{p}=0.0060)\end{array}$ \\
\hline
\end{tabular}


Original research

\begin{tabular}{|c|c|c|c|c|c|c|c|}
\hline Author & Title & Year & Journal & Relevance & Programme type & Outcome metric & Outcome result \\
\hline Martin et a $\left.\right|^{17}$ & $\begin{array}{l}\text { Evaluation of a clinical } \\
\text { leadership programme } \\
\text { for nurse leaders }\end{array}$ & 2012 & J Nurs Manag & Low & $\begin{array}{l}\text { Clinical leadership } \\
\text { programme focused } \\
\text { on leadership } \\
\text { competencies for nurse } \\
\text { leaders in Switzerland. } \\
\end{array}$ & $\begin{array}{l}\text { Observer- } \\
\text { reported scores } \\
\text { on five leadership } \\
\text { competencies over } \\
\text { time: model the way, } \\
\text { inspire a shared vision, } \\
\text { challenge the process, } \\
\text { enable others to act } \\
\text { and encourage the } \\
\text { heart. }\end{array}$ & $\begin{array}{l}\text { Statistically significant } \\
\text { improvement on } \\
\text { observer-reported } \\
\text { scores for Inspire a } \\
\text { Shared Vision and } \\
\text { Challenge the Process. }\end{array}$ \\
\hline McAlearney et a $\left.\right|^{13}$ & $\begin{array}{l}\text { Developing effective } \\
\text { physician leaders: } \\
\text { changing cultures } \\
\text { and transforming } \\
\text { organizations }\end{array}$ & 2005 & Hospital Topics & Low & $\begin{array}{l}\text { Medical leadership } \\
\text { development } \\
\text { programme for } \\
\text { academic and } \\
\text { community physicians } \\
\text { at a hospital in Ohio. }\end{array}$ & $\begin{array}{l}\text { Self-report by } \\
\text { participants on their } \\
\text { current leadership, } \\
\text { their ability to } \\
\text { lead teams, their } \\
\text { ability to work in } \\
\text { teams and several } \\
\text { other dimensions, } \\
\text { before and after the } \\
\text { programme. }\end{array}$ & $\begin{array}{l}\text { Increases in self-report } \\
\text { on all dimensions. }\end{array}$ \\
\hline McDade et $a l^{69}$ & $\begin{array}{l}\text { Effects of participation } \\
\text { in the Executive } \\
\text { Leadership in Academic } \\
\text { Medicine (ELAM) } \\
\text { program on women } \\
\text { faculty's perceived } \\
\text { leadership capabilities }\end{array}$ & 2004 & $\begin{array}{l}\text { Academic } \\
\text { Medicine }\end{array}$ & Low & $\begin{array}{l}\text { Leadership skill } \\
\text { development, } \\
\text { mentoring and } \\
\text { networking for women } \\
\text { faculty members in } \\
\text { medical and dental } \\
\text { schools. }\end{array}$ & $\begin{array}{l}\text { Changes in self-report } \\
\text { on } 10 \text { constructs/skills } \\
\text { related to leadership. }\end{array}$ & $\begin{array}{l}\text { Statistically significant } \\
\text { improvement }(p<0.001) \\
\text { on all } 10 \text { constructs. }\end{array}$ \\
\hline Omar et $a l^{56}$ & $\begin{array}{l}\text { Training evaluation: } \\
\text { a case study of } \\
\text { training Iranian health } \\
\text { managers }\end{array}$ & 2009 & $\begin{array}{l}\text { Hum Resour } \\
\text { Health }\end{array}$ & Low & $\begin{array}{l}\text { Trainings for lower } \\
\text { level managers } \\
\text { given new roles and } \\
\text { responsibilities in a } \\
\text { newly decentralised } \\
\text { health system in Iran. }\end{array}$ & $\begin{array}{l}\text { Self-report of } \\
\text { participants stating } \\
\text { that knowledge was } \\
\text { used 'often' for } 12 \\
\text { skills. }\end{array}$ & $\begin{array}{l}\text { Respondents saying } \\
\text { they used knowledge } \\
\text { often ranged from } \\
\sim 25 \% \text { for 'leadership } \\
\text { role' to } ~ 77 \% \text { for 'work } \\
\text { effectively in a group'. }\end{array}$ \\
\hline Patel et al & $\begin{array}{l}\text { Building the pipeline: } \\
\text { the creation of a } \\
\text { residency training for } \\
\text { future physician leaders } \\
\text { in health care quality }\end{array}$ & 2015 & Acad Med & Low & $\begin{array}{l}\text { Healthcare } \\
\text { Leadership in Quality } \\
\text { (HLQ) programme } \\
\text { that included } \\
\text { integration into an } \\
\text { interprofessional } \\
\text { healthcare leadership } \\
\text { team. }\end{array}$ & $\begin{array}{l}\text { Knowledge of the } \\
\text { Quality Improvement } \\
\text { Knowledge } \\
\text { Assessment Tool } \\
\text { before and after } \\
\text { training. }\end{array}$ & $\begin{array}{l}\text { Statistically significant } \\
\text { increase }(p<0.05) \text { in } \\
\text { knowledge as assessed } \\
\text { by this tool. }\end{array}$ \\
\hline Pollitt $^{70}$ & $\begin{array}{l}\text { Guinness Northern } \\
\text { Counties begins to } \\
\text { build a coaching } \\
\text { culture }\end{array}$ & 2012 & $\begin{array}{l}\text { Training \& } \\
\text { Management } \\
\text { Development } \\
\text { Methods }\end{array}$ & Low & $\begin{array}{l}\text { Training for middle } \\
\text { managers on modern } \\
\text { leadership, team } \\
\text { branding, value for } \\
\text { money, influencing, } \\
\text { team development and } \\
\text { management change. }\end{array}$ & $\begin{array}{l}\text { Cost savings identified } \\
\text { during training of } \\
\text { middle managers. }\end{array}$ & $\begin{array}{l}\text { f900 } 000 \text { (compared } \\
\text { with } \mathrm{f} 108000 \\
\text { investment in training } \\
\text { programme). }\end{array}$ \\
\hline Porter et $a l^{57}$ & $\begin{array}{l}\text { The management } \\
\text { academy for public } \\
\text { health: a new } \\
\text { paradigm for public } \\
\text { health management } \\
\text { development }\end{array}$ & 2002 & $\begin{array}{l}J \text { Public Health } \\
\text { Manag Pract }\end{array}$ & Low & $\begin{array}{l}\text { Curriculum designed } \\
\text { to train teams of } \\
\text { managers on skills such } \\
\text { as managing money, } \\
\text { people and data. }\end{array}$ & $\begin{array}{l}\text { Self-reported } \\
\text { skill levels for } 10 \\
\text { competencies, such } \\
\text { as managing and } \\
\text { executing strategies, } \\
\text { managing people and } \\
\text { communication. }\end{array}$ & $\begin{array}{l}\text { Statistically significant } \\
\text { improvement } \\
(p<0.0001) \text { on all } 10 \\
\text { competencies. }\end{array}$ \\
\hline
\end{tabular}


Original research

\begin{tabular}{|c|c|c|c|c|c|c|c|}
\hline Author & Title & Year & Journal & Relevance & Programme type & Outcome metric & Outcome result \\
\hline Richman et a $\left.\right|^{24}$ & $\begin{array}{l}\text { Advancing women and } \\
\text { closing the leadership } \\
\text { gap: the Executive } \\
\text { Leadership in Academic } \\
\text { Medicine (ELAM) } \\
\text { program experience }\end{array}$ & 2001 & $\begin{array}{l}\text { Journal of } \\
\text { Women's Health } \\
\text { and Gender-Based } \\
\text { Medicine }\end{array}$ & Low & $\begin{array}{l}\text { Evaluation of ELAM } \\
\text { across participating } \\
\text { schools. }\end{array}$ & $\begin{array}{l}\text { Self-report of } \\
\text { performance on six } \\
\text { curricular areas from } \\
\text { the first three ELAM } \\
\text { classes (financial } \\
\text { management, career } \\
\text { advancement, } \\
\text { personal leadership, } \\
\text { converging paradigms } \\
\text { of academic and } \\
\text { corporate leadership, } \\
\text { emerging issues and } \\
\text { strategic planning). }\end{array}$ & $\begin{array}{l}\text { Increase in self- } \\
\text { reported performance } \\
\text { on all six curricular } \\
\text { areas }(p<0.0001) \text {. }\end{array}$ \\
\hline Richter et $a^{28}$ & $\begin{array}{l}\text { Evaluation results of } \\
\text { the CDC/ASPH Institute } \\
\text { for HIV Prevention } \\
\text { Leadership: a capacity- } \\
\text { building educational } \\
\text { program for HIV } \\
\text { prevention program } \\
\text { managers }\end{array}$ & 2007 & $\begin{array}{l}J \text { Public Health } \\
\text { Manag Pract }\end{array}$ & Low & $\begin{array}{l}\text { Capacity-building } \\
\text { programme for HIV } \\
\text { prevention programme } \\
\text { managers in minority- } \\
\text { based, community- } \\
\text { based organisations. }\end{array}$ & $\begin{array}{l}\text { Self-reported } \\
\text { frequency of and } \\
\text { confidence performing } \\
11 \text { relevant public } \\
\text { health prevention and } \\
\text { strategic planning and } \\
\text { management activities, } \\
\text { such as community } \\
\text { assessments, advocacy } \\
\text { and creating a } \\
\text { learning environment. }\end{array}$ & $\begin{array}{l}\text { Statistically significant } \\
\text { increase in self- } \\
\text { reported frequency } \\
\text { and confidence on all } \\
\text { activities. }\end{array}$ \\
\hline Saleh et $a l^{58}$ & $\begin{array}{l}\text { Evaluating the } \\
\text { effectiveness of public } \\
\text { health leadership } \\
\text { training: the NEPHLI } \\
\text { experience }\end{array}$ & 2004 & $\begin{array}{l}\text { American Journal } \\
\text { of Public Health }\end{array}$ & Low & $\begin{array}{l}\text { Yearlong experiential } \\
\text { programme aimed at } \\
\text { building and improving } \\
\text { the leadership } \\
\text { skills of current and } \\
\text { future public health } \\
\text { practitioners. }\end{array}$ & $\begin{array}{l}\text { Self-reported } \\
\text { competency levels } \\
\text { and frequency of } \\
\text { use of } 15 \text { leadership } \\
\text { practices, including } \\
\text { 'cope with and lead } \\
\text { changes in public } \\
\text { health practice' and } \\
\text { 'mobilize resources in } \\
\text { the community needed } \\
\text { to increase access to } \\
\text { public health services'. }\end{array}$ & $\begin{array}{l}\text { Statistically significant } \\
\text { ( } \mathrm{p}<0.05 \text { ) increase } \\
\text { on self-reported } \\
\text { competence for all } \\
\text { practices and on self- } \\
\text { reported frequency of } \\
\text { use for four practices } \\
\text { (cope with and lead } \\
\text { changes in public } \\
\text { health practice; deal } \\
\text { with cultural and ethnic } \\
\text { diversity in the context } \\
\text { of access to health } \\
\text { services; understand } \\
\text { the administrative, } \\
\text { social and political } \\
\text { implications of } \\
\text { alternative policy } \\
\text { options; use visual } \\
\text { representation of data } \\
\text { to identify public health } \\
\text { problems). }\end{array}$ \\
\hline Talbot et a $l^{71}$ & $\begin{array}{l}\text { Five Weekend National } \\
\text { Family Medicine } \\
\text { Fellowship Program for } \\
\text { faculty development }\end{array}$ & 1997 & Can Fam Physician & Low & $\begin{array}{l}\text { Five Weekend National } \\
\text { Family Medicine } \\
\text { Fellowship which } \\
\text { focuses on the } \\
\text { essentials of education, } \\
\text { management, } \\
\text { communication, critical } \\
\text { appraisal skills and } \\
\text { the principles of family } \\
\text { medicine to develop } \\
\text { leadership and team- } \\
\text { building skills for } \\
\text { faculty and community- } \\
\text { based physicians. }\end{array}$ & $\begin{array}{l}\text { Results of projects } \\
\text { completed as part of } \\
\text { the programme. }\end{array}$ & $\begin{array}{l}>20 \text { presentations } \\
\text { at College of Family } \\
\text { Physicians of } \\
\text { Canada (CFPC), }>10 \\
\text { publications being } \\
\text { developed and various } \\
\text { other applications of } \\
\text { projects (out of a total } \\
34 \text { projects). }\end{array}$ \\
\hline
\end{tabular}

Null effect 
Original research

\begin{tabular}{|c|c|c|c|c|c|c|c|}
\hline Author & Title & Year & Journal & Relevance & Programme type & Outcome metric & Outcome result \\
\hline Cummings et a/ ${ }^{64}$ & $\begin{array}{l}\text { Worklife improvement } \\
\text { and leadership } \\
\text { development study: a } \\
\text { learning experience } \\
\text { in leadership } \\
\text { development } \\
\text { and 'Planned' } \\
\text { organizational change }\end{array}$ & 2013 & $\begin{array}{l}\text { Health Care } \\
\text { Management } \\
\text { Review }\end{array}$ & Null effect & $\begin{array}{l}\text { Leadership } \\
\text { Development } \\
\text { Initiative to facilitate } \\
\text { organisational learning } \\
\text { among healthcare } \\
\text { managers at the } \\
\text { Alberta Cancer Board. }\end{array}$ & $\begin{array}{l}\text { Six subscales on the } \\
\text { Areas of Worklife } \\
\text { Survey: workload, } \\
\text { control, reward, } \\
\text { community, fairness } \\
\text { and values. }\end{array}$ & $\begin{array}{l}\text { No statistically } \\
\text { significant changes } \\
\text { in self-reported } \\
\text { worklife by initiative } \\
\text { participants. }\end{array}$ \\
\hline Wallen et $a^{63}$ & $\begin{array}{l}\text { Implementing } \\
\text { evidence-based } \\
\text { practice: effectiveness } \\
\text { of a structured } \\
\text { multifaceted } \\
\text { mentorship programme }\end{array}$ & 2010 & JAdv Nurs & Null effect & $\begin{array}{l}\text { Structured multifaceted } \\
\text { mentorship programme } \\
\text { designed to implement } \\
\text { evidence-based } \\
\text { practice (EBP). }\end{array}$ & $\begin{array}{l}\text { Comparison } \\
\text { of Mentorship } \\
\text { Program Group and } \\
\text { Comparison Group } \\
\text { on EBP beliefs, } \\
\text { organisational culture } \\
\text { and readiness, EBP } \\
\text { implementation, job } \\
\text { satisfaction, group } \\
\text { cohesion, nurse } \\
\text { retention index and } \\
\text { intent to leave. }\end{array}$ & $\begin{array}{l}\text { No statistically } \\
\text { significant differences } \\
\text { between control } \\
\text { and intervention } \\
\text { groups except for } \\
\text { an improvement on } \\
\text { EBP beliefs in the } \\
\text { intervention group. }\end{array}$ \\
\hline \multicolumn{8}{|l|}{ Qualitative study } \\
\hline $\begin{array}{l}\text { Boomer and } \\
\text { McCormack }^{34}\end{array}$ & $\begin{array}{l}\text { Creating the } \\
\text { conditions for growth: } \\
\text { a collaborative } \\
\text { practice development } \\
\text { programme for clinical } \\
\text { nurse leaders }\end{array}$ & 2010 & J Nurs Manag & Qualitative & $\begin{array}{l}\text { Leadership practice } \\
\text { development using } \\
\text { work-based and action } \\
\text { learning. }\end{array}$ & N/A & $\begin{array}{l}\text { Reports indicated } \\
\text { progress towards } \\
\text { various leadership skills, } \\
\text { including becoming } \\
\text { reflexive, becoming } \\
\text { proactive, valuing } \\
\text { teamwork, becoming a } \\
\text { facilitator and nursing } \\
\text { processes. }\end{array}$ \\
\hline Champagne et $a l^{72}$ & $\begin{array}{l}\text { Organizational impact } \\
\text { of evidence-informed } \\
\text { decision making } \\
\text { training initiatives: a } \\
\text { case study comparison } \\
\text { of two approaches }\end{array}$ & 2014 & Implement Sci & Qualitative & $\begin{array}{l}\text { Impact of two } \\
\text { programmes on } \\
\text { evidence-informed } \\
\text { decision-making } \\
\text { (EIDM). }\end{array}$ & $\mathrm{N} / \mathrm{A}$ & $\begin{array}{l}\text { Training programmes } \\
\text { can improve attitudes } \\
\text { towards EIDM and, } \\
\text { to a lesser extent, } \\
\text { conversion of these } \\
\text { attitudes into skills. }\end{array}$ \\
\hline Enterkin et $a l^{73}$ & $\begin{array}{l}\text { Clinical leadership } \\
\text { for high-quality care: } \\
\text { developing future ward } \\
\text { leaders }\end{array}$ & 2013 & J Nurs Manag & Qualitative & $\begin{array}{l}\text { Series of workshops } \\
\text { for improving personal } \\
\text { influencing skills, high- } \\
\text { impact communication, } \\
\text { creating a positive } \\
\text { ward environment, } \\
\text { leading service and } \\
\text { practice innovation, } \\
\text { managing change, } \\
\text { quality improvement } \\
\text { and managing staff } \\
\text { among ward leaders } \\
\text { (nurses). }\end{array}$ & N/A & $\begin{array}{l}\text { Participants reported } \\
\text { increased political, } \\
\text { organisational and self- } \\
\text { awareness, increased } \\
\text { confidence, feelings } \\
\text { of empowerment and } \\
\text { the ability to empower } \\
\text { others. }\end{array}$ \\
\hline
\end{tabular}


Table 1 Continued

\begin{tabular}{|c|c|c|c|c|c|c|c|}
\hline Author & Title & Year & Journal & Relevance & Programme type & Outcome metric & Outcome result \\
\hline Singer et $a l^{37}$ & $\begin{array}{l}\text { A case for safety } \\
\text { leadership team } \\
\text { training of hospital } \\
\text { managers }\end{array}$ & 2011 & $\begin{array}{l}\text { Health Care } \\
\text { Management } \\
\text { Review }\end{array}$ & Qualitative & $\begin{array}{l}\text { Safety Leadership Team } \\
\text { Training with modules } \\
\text { on (1) introduction and } \\
\text { appreciative inquiry, (2) } \\
\text { theoretical framework } \\
\text { and employee survey, } \\
\text { (3) simulation exercise } \\
\text { and debrief, (4) the } \\
\text { 'Game Plan' project } \\
\text { management exercise, } \\
\text { and (5) a follow-up } \\
\text { programme. }\end{array}$ & N/A & $\begin{array}{l}\text { Respondents } \\
\text { reported that the } \\
\text { training increased } \\
\text { behaviours such as } \\
\text { 'showing you really } \\
\text { care', 'demonstrating } \\
\text { a welcoming/ } \\
\text { nondefensive attitude', } \\
\text { 'encouraging speaking } \\
\text { up', 'facilitating } \\
\text { teamwork and } \\
\text { communication', 'taking } \\
\text { action', 'mobilizing } \\
\text { information' and } \\
\text { 'seeking input'. }\end{array}$ \\
\hline Singer et $a l^{74}$ & $\begin{array}{l}\text { Making time for } \\
\text { learning-oriented } \\
\text { leadership in } \\
\text { multidisciplinary } \\
\text { hospital management } \\
\text { groups }\end{array}$ & 2015 & $\begin{array}{l}\text { Health Care } \\
\text { Management } \\
\text { Review }\end{array}$ & Qualitative & $\begin{array}{l}\text { Safety Leadership Team } \\
\text { Training with modules } \\
\text { on (1) introduction and } \\
\text { appreciative inquiry, (2) } \\
\text { theoretical framework } \\
\text { and employee survey, } \\
\text { (3) simulation exercise } \\
\text { and debrief, (4) the } \\
\text { 'Game Plan' project } \\
\text { management exercise, } \\
\text { and (5) a follow-up } \\
\text { programme. }\end{array}$ & $\mathrm{N} / \mathrm{A}$ & $\begin{array}{l}\text { Learning-oriented } \\
\text { leadership which } \\
\text { promoted a mutually } \\
\text { supportive environment } \\
\text { and which specifically } \\
\text { made time for learning } \\
\text { facilitated achievement } \\
\text { of these outcomes. }\end{array}$ \\
\hline
\end{tabular}

ICU, intensive care unit; N/A, not applicable; NHS, National Health Service; QI, quality improvement; RN, registered nurse; SWOT, strengths, weaknesses, opportunities and threats.

the implementation of the programme in one of the highrelevance articles mentioned earlier, staff reported a statistically significant increase in support from their supervisors and in transformational (as opposed to transactional) leadership behaviours among programme participants, while also reporting a statistically significant decrease in 'passive avoidant' and 'laissez-faire' management styles. ${ }^{18}$ Similar benefits found in other studies included improved problem solving between groups and nursing leadership ${ }^{29}$; a reduction in the number of unprofessional behaviours that required intervention by the chair of a medical department or someone of similar stature ${ }^{32}$; increased practice of 'enabling others to act' by a leader ${ }^{33}$; increased valuing or practising of teamwork/collaboration ${ }^{34-37}$; increased respect or caring for $\operatorname{staff}^{36} 37$; increased availability and support to employees ${ }^{34} 36$; increased clarity of communication to staff $^{38}$; increased demonstration of supportive leadership behaviours towards subordinates ${ }^{19}$; and increased general workplace culture and morale. ${ }^{39}$ The majority of these studies did not test for statistical significance, and several used qualitative, rather than quantitative, research methodologies.

2. Improvements in patient satisfaction or other patient-related metrics. Several studies found improved patient satisfaction scores on Press Ganey surveys, with improved metrics including 'how well pain was controlled', 40 'nurses took time to listen ${ }^{40}$ and general satisfaction with services. ${ }^{32}$ Studies also found that various programmes were associated with a reduction in patient complaints ${ }^{32}$; improved communication between staff and patients ${ }^{343538}$; and improved continuity of care. ${ }^{38}$ None of these studies tested for statistical significance and some used qualitative research methodologies.

3. Achievement of a specific tangible benefit to the organisation associated with a project in the programme. Several development or training programmes included specific projects, and the success of these projects could directly benefit the sponsoring organisation. In one programme that focused on creating revenue-generating projects, $38 \%$ of all teams had generated revenue from their projects within 5 years after the training programme (for a total $\$ 4$ million across all projects), ${ }^{41}$ and another programme focused on training middle managers helped identify $£ 900000$ in cost savings (compared with $£ 108000$ investment in the training programme). Several programmes focused on improving management indicators for various clinical topics (eg, reduction in time from abnormal mammogram findings to definitive diagnosis, reduction in patient registration time, improvement in patient experience, and so on) found that programme participants had completed their projects ${ }^{23} 42$ or achieved improvements on key indicators. ${ }^{43}$ A leadership development programme in Egypt taught local health managers and their teams leadership and management skills with the aim to 'improve the quality and accessibility of health services' through performance improvement projects. In the first year of the programme, 8 of the 10 projects in the programme had achieved $95 \%$ of their self-determined health performance targets. ${ }^{44}$

4. Increased confidence/use of leadership and management skills by programme participants. Although the demonstration of and/or confidence in leadership/management competencies are not necessarily tangible benefits to an organisation, an improvement on these dimensions after training programmes could lead directly or indirectly to more tangible benefits. For example, one study identified a statistically significant improvement in the ability of managers to use a specific management tool (strengths, weaknesses, opportunities and threats analysis) after training. ${ }^{45}$ Similarly, other studies found managers increasingly being proactive in leadership roles, ${ }^{34}$ acting as a facilitator after their training, ${ }^{34} 37$ 'inspiring a shared vision' among staff, ${ }^{46} 47$ becoming more com- 
fortable with the demands expected of a leader ${ }^{27}$ and having more concrete knowledge of management practice ${ }^{264849}$ or QI techniques. One high-relevance study found statistically significant improvement in an objective measure of team leadership skills by paediatric residents participating in a leadership workshop. ${ }^{31}$ Various other studies using selfreport to measure confidence or use of specific leadership/ management skills also found improvements after a training programme. ${ }^{50-62}$ Note that all articles relying only on selfreport were considered 'low relevance' for the purposes of answering the research question and should not be considered strong evidence of a benefit to the organisation.

5. Miscellaneous effects/benefits. In addition to the four themes mentioned above, several articles identified miscellaneous effects or benefits. These effects were not normally documented across multiple studies. One study found that participants in leadership development programmes were more likely to hold a role as the chair of a national committee (eg, committees associated with professional associations), which could benefit the organisation by increasing its prestige. ${ }^{27}$ One study found that deans of academic medical centres who were more confident than female faculty who had participated in a leadership development programme were more likely than other female faculty to stay at their institution, although this finding was strictly a perception and not an actual observed effect. ${ }^{25}$ One study found a statistically significant increase in staff retention among participants in the training programme. ${ }^{30}$

6. Null results. Several studies found no statistically significant impact of leadership training on outcomes such as retention, ${ }^{1863}$ job satisfaction, ${ }^{1863}$ clinical outcomes ${ }^{18}$ or 'worklife' (ie, workload, control, fairness, and so on). ${ }^{64}$

\section{DISCUSSION}

This research identified limited evidence of several benefits to organisations from leadership/management development and training programmes. However, there was not substantial, quantified evidence that such programmes have direct, tangible benefits for organisations in the form of ROI, reduced turnover or other potentially desired outcomes. This finding is consistent with the finding by Frich et al that 'the majority of studies [on this topic] relied on learner satisfaction scores and self-assessed knowledge or behavioral change' ( $p$ 656). ${ }^{9}$ Nonetheless, the absence of evidence does not necessarily equate to the absence of an effect. Rather, this review suggests that further research and more robust evaluation methodologies are needed, since a low percentage of training programmes use organisational metrics to measure their impact, ${ }^{4}$ and since our review found a limited research base on this topic.

This review included a diverse array of programmes designed for a variety of executives and managers in many different types of organisations, with potentially different goals in mind. Given the broad range of types of programmes, it would be difficult to develop a cohesive framework that would effectively categorise all the different types of programmes. The findings suggest that no single programme format will provide a 'silver bullet' to address the needs of all executive leaders or managers in all organisations and that different training goals require different designs. In the absence of very clear evidence for a single way to deliver training programmes, programmes should consider various factors to help promote clarity in the design and evaluation process. These factors include organisational context in which the leaders/managers operate, the goals of the programme given that organisational context, the knowledge, skills and abilities that will most benefit the participants and the organisation in achieving these goals, the pedagogical modes (eg, didactic training, experiential exercise, simulation) that will best facilitate retention and application of the learning and the evaluation mechanisms to be used in measuring programme outcomes against stated goals.

\section{Limitations of this research and risk of bias}

As already noted, the ability to draw conclusions about the impact of leadership and management training programmes at the organisational level is limited by the restricted evidence base on this topic. In addition to the fact that the research base and associated methods are limited in general (with only two randomised controlled trials), there are several risks for bias in the literature. First, institutions, particularly for-profit companies, are unlikely to publish ROI analyses or other financial data about their programmes. Among the information that is published, institutions are more likely to publish findings with positive results that reflect well on themselves. Indeed, while we found two articles with null results, we found that negative results were rarely if ever reported. Self-report introduces considerable bias into the evaluation of programmes' effectiveness, which is why all articles relying solely on self-report were considered low relevance for our study.

\section{Directions for future research}

More research is needed on the impact of leadership and management training programmes at the organisation level. Although research on the direct financial implications of programmes at private institutions may be difficult to conduct or report publicly, research on other benefits to the organisation which could indirectly have positive financial impacts would also be relevant for the literature. Possible outcomes of interest include patient satisfaction, patient safety and other outcomes, staff retention and performance on quality criteria. In addition, research efforts should continue to analyse the various factors which promote or impede the success of leadership and management training programmes, and how these factors have differential impact on different types of outcomes. Academic medical centres could be particularly well positioned to conduct further research on this topic. Finally, despite the complex nature of evaluating programmatic effectiveness in large organisations, it is important for researchers to use rigorous methods in assessing leadership/ management development programmes, given only two highrelevance articles included in this review used a randomised controlled trial design.

\section{CONCLUSION}

Although leadership and management training programmes are widespread, the research on their tangible impacts at the organisational level, such as a ROI, is very limited right now. Our research identified at least four potential effects/benefits of these types of programmes at the organisational level: benefits to other staff in the organisation, improvements in patient satisfaction or safety, achievement of specific project-related goals and increased confidence using leadership-related skills by programme participants. However, given the limited evidence base on this topic, more research is needed to identify the institution-level benefits of investing in these types of programmes.

Acknowledgements The authors thank Jonty Roland at KPMG for his input in structuring the research question and overall approach. The authors thank Nancy Kane and Sara Singer at Harvard T H Chan School of Public Health for their extensive 
input into the research approach, multiple drafts of the manuscript and the list of articles to include in the review.

Contributors GS, LP and JM all conceived the research question and overall approach. GS designed the research protocol with two Harvard librarians. GS conducted a first review all articles in the database and wrote the first draft of the manuscript. GS, LP and JM all edited subsequent versions of the manuscript and recommended additional articles not originally included in the first database search.

Funding An original draft of this paper was commissioned by KPMG.

Competing interests None declared.

Patient consent for publication Not required.

Provenance and peer review Not commissioned; externally peer reviewed.

Data availability statement All data relevant to the study are included in the article or uploaded as supplementary information.

Open access This is an open access article distributed in accordance with the Creative Commons Attribution Non Commercial (CC BY-NC 4.0) license, which permits others to distribute, remix, adapt, build upon this work non-commercially, and license their derivative works on different terms, provided the original work is properly cited, appropriate credit is given, any changes made indicated, and the use is non-commercial. See: http://creativecommons.org/licenses/by-nc/4.0/.

\section{ORCID iD}

Gabriel Seidman http://orcid.org/0000-0002-9167-2595

\section{REFERENCES}

1 Dubinsky I, Feerasta N, Lash R. A model for physician leadership development and succession planning. Healthc Q 2015;18:38-42.

2 National Center for Healthcare Leadership. Physician leadership development programs: best practices in healthcare organizations, 2014. Available: http://www. nchl.org/Documents/Ctrl_Hyperlink/NCHL_Physician_Leadership_Development_ White_Paper_Final_05.14_uid9142015803251.pdf

3 NHS Leadership Academy. Annual review: 2014-2015, 2015.

4 McAlearney AS. Executive leadership development in U.S. health systems. J Healthc Manag 2010;55:206-24. discussion 223-204.

5 West M, Armit K, Loewenthal L, et al. Leadership and leadership development in healthcare: the evidence base. London: Faculty of Medical Leadership and Management, 2015.

6 McGahan AM, Porter ME. What do we know about variance in accounting profitability? Manage Sci 2002;48:834-51.

7 Huselid MA. The impact of human resource management practices on turnover, productivity, and corporate financial performance. Academy of Management J 1995;38:635-72.

8 Anderson MM, Garman AN. Leadership development in healthcare systems: towards an evidence-based approach, 2014.

9 Frich JC, Brewster AL, Cherlin EJ, et al. Leadership development programs for physicians: a systematic review. J Gen Intern Med 2015;30:656-74.

10 PRISMA. PRISMA: transparent reporting of systematic reviews and meta-analyses, 2015. Available: http://www. prisma-statement.org/ [Accessed 6 Sep 2016].

11 Whitsell LJ. Learning disorders as a school health problem. Neurological and psychiatric aspects. Calif Med 1969;111:433-45.

12 McAlearney AS. Leadership development in healthcare: a qualitative study. J Organ Behav 2006:27:967-82.

13 McAlearney AS, Fisher D, Heiser K, et al. Developing effective physician leaders: changing cultures and transforming organizations. Hosp Top 2005;83:11-18.

14 Hardacre J, Cragg R, Shapiro J, et al. What's leadership go to do with it? exploring links between quality improvement and leadership in the NHS. The Health Foundation, 2011.

15 Hughes RG. Chapter 44 Tools and Strategies for Quality Improvement and Patient Safety. In: Hughes RG, ed. Patient safety and quality: an evidence-based Handbook for nurses. Rockville (MD): Agency for Healthcare Research and Quality (US), 2008.

16 Ellard DR, Chimwaza W, Davies D, et al. Can training in advanced clinical skills in obstetrics, neonatal care and leadership, of Non-physician clinicians in Malawi impact on clinical services improvements (the ETATMBA project): a process evaluation. BMJ Open 2014;4:e005751.

17 Ellard DR, Shemdoe A, Mazuguni F, et al. Can training Non-physician clinicians/ associate clinicians (NPCS/ACs) in emergency obstetric, neonatal care and clinical leadership make a difference to practice and help towards reductions in maternal and neonatal mortality in rural Tanzania? the ETATMBA project. BMJ Open 2016:6:e008999.

18 Jeon Y-H, Simpson JM, Li Z, et al. Cluster randomized controlled trial of an aged care specific leadership and management program to improve work environment, staff turnover, and care quality. J Am Med Dir Assoc 2015;16:629.e19-e28.

19 Shirazi M, Emami AH, Mirmoosavi SJ, et al. The effects of intervention based on supportive leadership behaviour on Iranian nursing leadership performance: a randomized controlled trial. J Nurs Manag 2016;24:400-8.
20 Cordes $\mathrm{DH}$, Rea $\mathrm{DF}$, Rea J, et al. A program of management training for residents. Acad Med 1989;64:45-6.

21 Stoller JK, Rose M, Lee R, et al. Teambuilding and leadership training in an internal medicine residency training program. J Gen Intern Med 2004;19:692-7.

22 Weiss RL. A clinical laboratory management elective for pathology residents. Arch Pathol Lab Med 1992;116:108-10.

23 Foster T, Regan-Smith M, Murray C, et al. Residency education, preventive medicine, and population health care improvement: the Dartmouth-Hitchcock leadership preventive medicine approach. Acad Med 2008;83:390-8.

24 Richman RC, Morahan PS, Cohen DW, et al. Advancing women and closing the leadership gap: the executive leadership in academic medicine (ELAM) program experience. J Womens Health Gend Based Med 2001;10:271-7.

25 Dannels S, McLaughlin J, Gleason KA, et al. Medical school deans' perceptions of organizational climate: useful indicators for advancement of women faculty and evaluation of a leadership program's impact. Acad Med 2009;84:67-79.

26 Crites GE, Schuster RJ. A preliminary report of an educational intervention in practice management. BMC Med Educ 2004;4.

27 Day CS, Tabrizi S, Kramer J, et al. Effectiveness of the AAOS leadership fellows program for orthopaedic surgeons. J Bone Joint Surg Am 2010;92:2700-8.

28 Richter DL, Dauner KN, Lindley LL, et al. Evaluation results of the CDC/ ASPH Institute for HIV prevention leadership: a capacity-building educational program for HIV prevention program managers. J Public Health Manag Pract 2007; Suppl:S64-71.

29 Boyle DK, Kochinda C. Enhancing collaborative communication of nurse and physician leadership in two intensive care units. J Nurs Adm 2004;34:60-70.

30 Chang S, Morahan PS, Magrane D, et al. Retaining faculty in academic medicine: the impact of career development programs for women. J Womens Health 2016;25:687-96. 2002

31 Gilfoyle E, Gottesman R, Razack S. Development of a leadership skills workshop in paediatric advanced resuscitation. Med Teach 2007;29:e276-83.

32 Hultman CS, Halvorson EG, Kaye D, et al. Sometimes you can't make it on your own: the impact of a professionalism curriculum on the attitudes, knowledge, and behaviors of an academic plastic surgery practice. J Surg Res 2013;180:8-14.

33 Duygulu S, Kublay G. Transformational leadership training programme for charge nurses. J Adv Nurs 2011:67:633-42.

34 Boomer CA, McCORMACK B. Creating the conditions for growth: a collaborative practice development programme for clinical nurse leaders. J Nurs Manag 2010; 18:633-44

35 West B, Lyon MH, McBain M, et al. Evaluation of a clinical leadership initiative. Nurs Stand 2004;19:33-41.

36 Tumerman M, Carlson LMH. Increasing medical team cohesion and leadership behaviors using a 360-degree evaluation process. WMJ 2012;111:33-7.

37 Singer SJ, Hayes J, Cooper JB, et al. A case for safety leadership team training of hospital managers. Health Care Manage Rev 2011;36:188-200.

38 DIERCKX de CASTERLÉ B, Willemse AN, Verschueren M, et al. Impact of clinical leadership development on the clinical leader, nursing team and care-giving process: a case study. J Nurs Manag 2008;16:753-63.

39 Haseman BC, Crethar MP, Phillips JN, et al. Practising inspired leadership: the use of applied theatre "prophetical" in the executive Leadership Development Program for Queensland Health. Aust Health Rev 2009:33:377-81.

40 Anonymous. Assessment tool helps Hospital conquer challenges. $T+D$ 2006:60:68-9.

41 Orton S, Umble K, Zelt S, et al. Management Academy for public health: creating entrepreneurial managers. Am J Public Health 2007:97:601-5.

42 Levine SA, Chao SH, Brett B, et al. Chief resident immersion training in the care of older adults: an innovative interspecialty education and leadership intervention. J Am Geriatr Soc 2008:56:1140-5.

43 Green PL, Plsek PE. Coaching and leadership for the diffusion of innovation in health care: a different type of multi-organization improvement collaborative. Jt Comm J Qual Improv 2002;28:55-71.

44 Mansour M, Mansour JB, Swesy AHE. Scaling up proven public health interventions through a locally owned and sustained leadership development programme in rural upper Egypt. Hum Resour Health 2010;8:1.

45 Terzic-Supic Z, Bjegovic-Mikanovic V, Vukovic D, et al. Training Hospital managers for strategic planning and management: a prospective study. BMC Med EduC 2015;15:25.

46 Bowles A, Bowles NB. A comparative study of transformational leadership in nursing development units and conventional clinical settings. J Nurs Manag 2000;8:69-76.

47 Martin JS, McCormack B, Fitzsimons D, et al. Evaluation of a clinical leadership programme for nurse leaders. J Nurs Manag 2012;20:72-80.

48 LoPresti L, Ginn P, Treat R. Using a simulated practice to improve practice management learning. Fam Med 2009;41:640-5.

49 Brandon CJ, Mullan PB. Teaching medical management and operations engineering for systems-based practice to radiology residents. Acad Radiol 2013;20:345-50.

50 Brinkert R. Conflict coaching training for nurse managers: a case study of a twohospital health system. J Nurs Manag 2011;19:80-91.

51 Burns M, Papa A. Self-Reported changes in nurse manager proficiency resulting from participation in the rising StAR leadership program. Pa Nurse 2008;63:12. 
52 Dannels SA, Yamagata H, McDade SA, et al. Evaluating a leadership program: a comparative, longitudinal study to assess the impact of the executive leadership in academic medicine (ELAM) program for women. Acad Med 2008;83:488-95.

53 Group Health Research Institute. NLAPH Cohort 2 evaluation report: executive summary. National Leadership Academy for the Public's Health, 2014.

54 Hanna WC, Mulder DS, Fried GM, et al. Training future surgeons for management roles: the resident-surgeon-manager conference. Arch Surg 2012;147:940-4.

55 Krejci JW, Malin S. Impact of leadership development on competencies. Nurs Econ 1997;15:235-41.

56 Omar M, Gerein N, Tarin E, et al. Training evaluation: a case study of training Iranian health managers. Hum Resour Health 2009;7:20.

57 Porter J, Johnson J, Upshaw VM, et al. The management Academy for public health: a new paradigm for public health management development. J Public Health Manag Pract 2002;8:66-78.

58 Saleh SS, Williams D, Balougan M. Evaluating the effectiveness of public health leadership training: the NEPHLI experience. Am J Public Health 2004;94:1245-9.

59 Fiset $\mathrm{V}$, Luciani $T$, Hurtubise $A$, et al. Clinical nursing leadership education in long-term care: intervention design and evaluation. J Gerontol Nurs 2017;43:49-56.

60 Hartley R, Garrett W. Impact of a management assessment centre in developing proficient health managers. Aust Health Rev 1997;20:119-27.

61 Leslie LK, Miotto MB, Liu GC, et al. Training young pediatricians as leaders for the $21 \mathrm{st}$ century. Pediatrics 2005;115:765-73.

62 Farver CF, Smalling S, Stoller JK. Developing leadership competencies among medical trainees: five-year experience at the Cleveland clinic with a chief residents' training course. Australas Psychiatry 2016;24:499-505.

63 Wallen GR, Mitchell SA, Melnyk B, et al. Implementing evidence-based practice: effectiveness of a structured multifaceted mentorship programme. J Adv Nurs 2010;66:2761-71.
64 Cummings GG, Spiers JA, Sharlow J, et al. Worklife Improvement and Leadership Development study: a learning experience in leadership development and "planned" organizational change. Health Care Manage Rev 2013;38:81-93.

65 Anderson M, Lavoie-Tremblay M. Evaluation of the executive training for research application (extra) program: design and early findings. Hcpol 2008;4:e136-48.

66 Cooper SJ. An evaluation of the leading an empowered organisation programme. Nurs Stand 2003:17:33-9.

67 Edler A, Adamshick M, Fanning R, et al. Leadership lessons from military education for postgraduate medical curricular improvement. Clin Teach 2010;7:26-31.

68 Korschun HW, Redding D, Teal GL, et al. Realizing the vision of leadership development in an academic health center: the Woodruff leadership Academy. Acad Med 2007;82:264-71.

69 McDade SA, Richman RC, Jackson GB, et al. Effects of participation in the executive leadership in academic medicine (ELAM) program on women faculty's perceived leadership capabilities. Acad Med 2004;79:302-9.

70 Pollitt D. Guinness Northern counties begins to build a coaching culture. Training \& Management Development Methods 2012;26:585-90.

71 Talbot Y, Batty H, Rosser WW. Five weekend national family medicine fellowship. program for faculty development. Can Fam Physician 1997;43:2151-7.

72 Champagne F, Lemieux-Charles L, Duranceau M-F, et al. Organizational impact of evidence-informed decision making training initiatives: a case study comparison of two approaches. Implement Sci 2014;9.

73 Enterkin J, Robb E, McLaren S. Clinical leadership for high-quality care: developing future ward leaders. J Nurs Manag 2013;21:206-16.

74 Singer SJ, Hayes JE, Gray GC, et al. Making time for learning-oriented leadership in multidisciplinary hospital management groups. Health Care Manage Rev 2015;40:300-12 